ORIGINAL ARTICLE

\title{
Unmasking Nation/Rewriting Home: Gendered Narratives of the Partition and its Aftermath
}

\author{
Rashmi Luthra \\ Department of Language, Culture and Communication, Public Communication and Culture Studies, University \\ of Michigan - Dearborn, Dearborn, MI, 48128, USA
}

\begin{abstract}
This essay examines personal narratives and gender-sensitive fictional representations of the Partition between India and Pakistan to contribute to a counterhistory that takes centrally into account the ways in which nation formation was written on the bodies of women. The juxtaposition of my mother's stories, the oral histories gathered by feminist historiographers, and critical analyses of Partition-related fiction, allows us to see the limitations and potential of each. While dominant ideologies are seen to seep into the narratives, each in its own way also goes beyond the dominant version of Partition history to lay the ground for new ways of understanding and imagining the pain that women experienced and the responses they made to circumstances not of their own making.
\end{abstract}

doi:10.1111/j.1753-9137.2012.01122.x

In this essay, I examine gendered narratives of a crucial historical moment in the history of the South Asian subcontinent, the Partition between India and Pakistan, in an attempt to clear further space for interpretations of this momentous event that splinter dominant understandings; by using a combination of personal narratives, oral histories gathered by South Asian feminists, and already existing analysis of fictional narratives, I build on others to continue to piece together a counterhistory.

The carving out of new spaces of enunciation is particularly important when women become implicated in large-scale upheavals definitional of national and community boundaries, and when their bodies become instruments in the defining of boundaries. As Mankekar (1999, p. 8) points out, borrowing from Chakravarti (1989), Sangari and Vaid (1989), and Mani (1989), "Representations of Indian Womanhood were a major site of contention in colonial and anticolonial discourses, in which women were often represented as icons and 'carriers' of tradition." While the figure of the victimized woman was deployed by the British in the context of the attempted abolition of sati (Mani, 1989; Spivak, 1987), the "woman question"

Corresponding author: Rashmi Luthra; e-mail: rluthra@umich.edu 
again became central in the Indian subcontinent during the Indian independence movement; the Indian woman as sign became the bearer of an interior spirituality and moral tenor marking the border between Indian-ness and British-ness (Chatterjee, 1989; Rajan, 1993). What has remained relatively obscure until recently is the gendered aspect of the monstrous underside of the formation of the nation; the ways in which woman as sign and women in actuality were used to demarcate boundaries between communities and nations during the Partition between India and Pakistan (Butalia, 1998; Menon \& Bhasin, 1998). In focusing on this particular historical juncture and in juxtaposing different kinds of marginal narratives speaking to the gendered aspects of the violent drawing of borders as two nations were created, I seek to contribute to an existing body of knowledge on how nation formation and nationalisms are written upon and through the bodies of women, both literally and metaphorically. Anthias and Yuval-Davis (1992) show how in different contexts the discourse of nationalism uses women as key signifiers, how women are implicated in both the symbolic construction of nationalism but also in the process of nationalism, of creating and solidifying the boundaries that define national and ethnic categories at the level of ideology and practice. Although the exact idioms by which women are incorporated into the nationalist agenda vary significantly by context, responding to both the specific forms of imperialism against which nationalisms are forged and the internal conditions upon which the process of nation formation is based, a recurring strain is the central role of "woman" both as the physical and metaphorical terrain upon which national and ethnic identities are created and reinforced. Just as the specific contours of Orientalist constructs within which the figure of "woman" is subsumed vary significantly by specific context, the nationalist response to these imposed constructs that also subsume "woman" as sign is differentiated in different contexts of time and space (Jayawardena, 1986; Jiwani, 2006; Lowe, 1991). In this article, I am interested in probing one such specific context to which I have a historical and emotive connection as an Indian diasporic woman whose parents, Hindu, upper middle class, and upper caste, were part of the transfer of population from the newly created Pakistan to India. And although I acknowledge, as has been well documented, that masculinities are implicated along with femininities in the forging of both old and new nationalisms (Bhattacharyya, 2008; Sinha, 1995), I focus here on women's experience, to further unearth subjugated knowledges that have been interred in the male-centric, dominant writings and readings of the Partition.

\section{Historical and theoretical background}

The British had colonized India for over 300 years, with the first foothold being gained in 1612 with the establishment of the East India Company, and an entrenchment of British rule from 1858 onward (the period from 1848 to 1947 is referred to as the British Raj). Although there had been significant resistance against British rule as early as the widespread mutiny against the British Company rule in 1857, the Indian independence movement really took root in the early 1900s, culminating in 
the dismantling of British rule in 1947. As the independence movement gained steam in the early 1900s, the question of minority status for Muslims in an independent India came onto the agenda. A number of factors gradually intensified the misgivings and fears of the Muslim community regarding their prospective status in a Hindumajority India, culminating in the demand for an independent state for Muslims, and leading finally to the Partition of the territory in August 1947 into Hindumajority states constituting India and Muslim-majority states constituting Pakistan. The mistrust and violence leading up to the Partition, as well as the chaos resulting from a massive transfer of populations, resulted in large-scale bloodshed. The nationalist paradigm, taking as its starting point the logic of nation formation, has dominated understandings of Partition, resulting in a submergence of experiences and interpretations that lay bare the contingency and partiality of the paradigm itself. In many ways, the position of women in relation to the Partition was highly contradictory, with women becoming pawns in the process of drawing boundaries between communities and nations (Butalia, 1998; Menon \& Bhasin, 1998). Making room for women's experiences and gendered understandings during this cataclysmic period is crucial in enabling a more complete understanding of the implications of nation formation. Further, because women were deployed at a physical and symbolic level in the construction of boundaries between communities and nations, opening up new points of enunciation for women allows us not only to understand the cost of boundary formation, but also to understand and imagine ways in which women inhabit, respond to, and resist the creation of borders beyond the ones imputed by the dominant nationalist paradigm. Also, because the regulation of women's sexuality as a crucial site of patriarchy was at stake in many of the debates and dominant narratives surrounding the problematic of abducted women, exploring counternarratives in this area serves to expand the palette of women's sexuality (Menon \& Bhasin, 1998, p. 20).

As Menon observes, "The Partition of India in 1947 recorded one of the most massive peace-time upheavals ever, and it is generally agreed that its reverberations persisted and are still being felt, with varying degrees of intensity, in the three countries most affected by it" (2004, p. 2). Approximately 10-12.5 million people moved in both directions across the newly created border between the newly created countries of Pakistan and India, becoming dispossessed in one way or the other, and approximately one million perished in the process, a significant portion violently so. Approximately 75,000 women were abducted in the process (Butalia, 1998; Menon \& Bhasin, 1998). Women experienced violence at the hands of the enemy, including rape, mutilation, branding with religious symbols, and forced abduction of Muslim women by Hindu men and vice versa, as well as poisoning, electrifying, decapitation, immolation, and other forms of violence at the hands of their own community as a means to preserve the purity of the religion by avoiding abduction and possible rape at all costs (Menon \& Bhasin, 1998). It is therefore crucial to explore the ways in which the history of the Partition is being rewritten from the margins. Reconfiguring our understandings of this defining moment and the subsequent communal strife (the fraught relations between religious communities, particularly Hindu and Muslim) 
in the region is essential in expanding the space from which imaginative solutions might be broached.

\section{Giving centrality to gendered narratives of the partition}

It has taken nearly half a century for the history of the Partition between Pakistan and India to be rewritten from a quotidian, gendered perspective that helps to puncture the more formal centrist and nationalist perspectives on nation formation and citizenship although exploration of alternative perspectives was taking place in film and literary work in the interim. Whereas official, often male-centric, perspectives have tended to solidify borders, people's, particularly gendered perspectives, have slipped beneath and around those borders, weighing the cost of demarcation, probing threshold existence that defies the slicing of peoples and cultures, searching for new ways to suture identities. This work has entailed fiction and nonfiction, sometimes working at the interstices of the two. Foremost in the domain of nonfiction has been the groundbreaking work of Menon and Bhasin (1998) and Butalia (1998), in the tradition of feminist historiography. These particular scholars have chosen the Partition as their focal point because of its centrality to the understanding of India as a nation, and because of the deep traces the upheaval has left in terms of the social and political contours of both India and Pakistan. It becomes crucial to do a gendered history of this critical juncture in order to grasp its significance more fully. Menon and Bhasin explain the importance of doing a gendered and self-reflexive history thus:

The issue of gendered identities is central to any discussion on the interplay of community, class, and caste with wider political, economic, and social forces. The adoption of a perspective that locates women at the intersection of these forces rather than at the periphery, casts an entirely new light on the apparent fixity of defining features of identity; indeed, the presence, absence, and precise location of women turns out to be one of the crucial elements that throws these "fixed" identities into disarray and confusion. Thus, are we made to look anew at those age-old borders and boundaries: nation, religion, community, gender; those ancient myths about shame and honor, blood and belonging (p. 21).

Menon and Bhasin also discuss "the importance of literary, autobiographical, oral historical, and fragmentary material for an understanding of Partition." The significance of what she terms as "fragment" is precisely that it is marginal, not official, and therefore takes us beyond the official version of memory and history. She says poignantly that "different sorts of telling reveal different truths" (Menon \& Bhasin, 1998, p. 8). I have taken this as the starting point of my own inquiry, juxtaposing my mother's stories about the Partition with the oral histories collected by Menon and Bhasin (1998) and Butalia (1998), and with literary renditions of gendered aspects of the Partition, to understand both the presences and absences in each, and what these can tell us about women's position in relation to this defining historical moment. My critical inquiry of the narratives is informed by questions 
having to do with the extent to which the marginal narratives reinscribe the dominant narratives, but more crucially where they diverge from the dominant interpretations. I ask: What master narratives inform the stories my mother has told me repeatedly? In what ways do her constructions both duplicate and contest the official narratives? How do other women's oral histories relate to her accounts, and what do these tell us about the limits and possibilities therein? In what ways do the fictional reworkings relate to her accounts and in what ways do these allow us to go beyond what have become common-sense understandings of the Partition and its aftermath, especially in terms of its gendered aspects?

With my mother's stories as the beginning point of my research, I use other nonfictional and fictional accounts to pry open the stories for deeper meaning, and to more fully understand the ideologies that underpin and authorize these stories, the limits therein, and how these might be opened up to more liberating possibilities in terms of how women are constituted as subjects, especially in relation to the ongoing constitution and reconstitution of boundaries defining community and nation. The autoethnographic elements are used critically here, as a window to understand the play of power in language and memory, the shaping of memory by dominant ideologies. Even while using personal accounts as a window to the daily lived experience and quotidian understandings of Partition, framing individual stories in the context of the bigger story of the creation of borders, the partiality and selectivity of the stories is acknowledged, and they are purposely juxtaposed against other kinds of narratives to probe the limits and possibilities of each (Chang, 2008).

\section{My mother's stories and women's oral histories}

I will start then with my mother's accounts. She explains that as the violence intensified in August 1947 her mother became very anxious about safeguarding her four daughters' well being. She beseeched her son, that is my mother's brother, to start packing up to leave Lyallpur (the borders had been drawn and Lyallpur was now considered to be in the newly created Pakistan). She said, "How many sisters will you safeguard? You are one and they are four." He was the only male in the household, my grandfather having expired when my mother was seven. To reassure his mother, he would tell her repeatedly, "I carry vials of cyanide in my pocket. If anyone attacks us, I will give one each to my sisters and then take one myself. I will not allow them to be robbed of their honor (izzat)." My mother explains that as a doctor, he had access to cyanide. She says this with much satisfaction, as one who felt protected by her brother. ${ }^{1}$

Opening out from my mother's vignette, then, I read of the vials of poison in Ritu Menon's account, based on her interviews with dozens of women in India and Pakistan. She says, "For hundreds - no, thousands - of women, to travel fearfully often meant never to arrive. Venturing out could entail being ambushed, injured, abducted, raped, killed, converted, and forcibly married. Or it could mean embracing death. Many carried vials of poison around their necks to be consumed in case they 
were captured, several showed up long after their families had abandoned hope of ever seeing them again" (Menon, 2004b, p. 133). I also read accounts in Urvashi Butalia's The Other Side of Silence of women in an area of Punjab who had jumped into wells to avoid being captured. The well in one location overflowed with the bodies of women (Butalia, 1998, p. 151). Durga Rani, interviewed by Menon and Bhasin (1998) tells a similar story. "In the villages of Head Junu, Hindus threw their young daughters into wells, dug trenches and buried them alive. Some were burnt to death, some were made to touch electric wires to prevent the Muslims from touching them" (p. 32). My mother had spoken of women jumping into wells; it had come to her as a rumor during the days of Partition. Through these accounts a more structured and at the same time multilayered understanding began to take shape. In this parceling out of people, places, and belongings, borders were being drawn on the bodies of women too. In an attempt to prevent "our" women from being defiled by "their" men, it became conceivable to take the very lives of women in one's own family to avoid what came to be construed as a worse fate. Indeed, it became psychologically possible for women themselves to commit suicide when this became construed as martyrdom. Butalia observes that "The violence that women faced in the aftermath of Partition is shrouded in many layers of silence. If we hear little about the rape and abduction of women in historical accounts, what we do know about violence in general relates only to men of the 'other' community" (1998, p. 146). When stories of women's deaths at the hands of their own men are told, they are always couched in the language of martyrdom to save the purity of the religion. Although in the case of my mother this possibility was not actualized, and it is not possible to say what she would have done should the situation have presented itself, she speaks of the cyanide as a liberating option. As with the oral histories gathered by Menon and Butalia, any contradictory feelings the women might have experienced become papered over by stories of their potential or actual "valor." The women's accounts, including my mother's, borrow from a larger moral economy of honor and shame, of "their men" as potential violators and "our men" as certain protectors, erasing gray areas, threshold spaces that would lead us to new understandings of the contingency of border creation, the arbitrary construction of the barbaric masculinity by which the "other" is painted, the shared experiences of violation and loss across communities, the sexual exploitation of women by men of one's own community as well as the others,' and the complex workings of women's agency as they negotiated difficult circumstances and limited choices. In the selective appropriation of experience in the form of memory, and the selective appropriation of the remembered in the creation of stories told to the next generation, signs of contradiction, traces of resistance to the dominant paradigm, become submerged. The stories themselves are motivated by present concerns that include, but are not exhausted by, the need to consolidate the border between countries and communities, as part of the valorization of collective sacrifice and survival.

Yet everything is not sewn up neatly, either in the oral histories or my mother's stories. Traces of resistance emerge as cross-currents in both, although in my mother's 
stories this constitutes a very faint strain. She speaks of studying for exams during the evenings in the summer of 1947, as disturbances were beginning. One evening, she dropped her glass of milk and ran upstairs to the rooftop to join her family as she heard alarming cries of women shouting "Run, run!! Save me, save me!!" (Bhago, bhago! Bachao, bachao!). She says she had repeated nightmares with the women's cries for years after the Partition. She never places the religious affiliation of the women, it is the suffering of the women that she could not excise from her memory for some time. It is the potential victimization of all women, the drawing of borders in and through the rape and abduction of women, this is the terrible trace in her nightmares. In the oral histories, the faint association with abduction in my mother's stories becomes a much more palpable presence. Menon and Bhasin (1998) and Butalia (1998) give many detailed accounts of women abducted during the Partition, and sometimes forcibly married. Menon and Bhasin interweave interviews of abducted women and social workers with government documentation to show how women were, sometimes against their wish, repatriated to what was determined to be their "country." Especially on the Indian side, this became highly problematic because the Hindu women would often be repudiated by their own families and placed in ashrams (homes opened for the purpose of rehabilitation of repatriated women). In this way, women's actual lives and choices were subsumed to notions of honor. ${ }^{2}$ Ironically, the creation of the new nations laid bare the gendered contours of the process; the abducted and repatriated women had no home, no country to call their own. For them the accoutrements of citizenship rang hollow. Even though the stories ritualized and rehearsed by the community amplify the martyrdom of women who committed suicide or were killed by their own relatives to protect them from rape and possible dismemberment, women social workers' testimonies help to resuscitate other possibilities. As social worker Anis Kidwai describes eloquently, "there were some women who had been born into poor homes and had not seen anything other than poverty ... and now they had fallen into the hands of men who brought them silken salwars and net dupattas. Why should they leave such men and go back to covering their bodies with rags ..." (Butalia, 1998, p. 113). In fact, social workers' testimonies give evidence of many women having "taken advantage of the social turmoil to marry men of their choice from outside the community, something that would have been almost certainly disallowed in more normal times" (Menon \& Bhasin, 1998, p. 24). Through the testimonies of the social workers, and because of their own conflicted feelings as a result of their empathy with the abducted women, other hues of experience open up to us. Rather than wrapping up the story of women in the Partition as one of either victimization or martyrdom, it becomes possible to recognize other spaces that were inhabited, such as a latching onto life itself, and to life's bodily pleasures. The possibility also has to be then admitted of developing new attachments, or living with a kind of detachment. In addition, the palette of women's agency widens appreciably, with positions ranging from forming affirmative relationships with men deemed as the "other" to the refusal to be forcibly repatriated. Whereas the official history of Partition, and to a large extent family 
narratives, insisted on religious identification and religious purity, a counterhistory lies in a range of responses and positions taken by women, including transacting with those deemed as the enemy. As Anis Kidwai points out, women have a contradictory relationship to formal religion in any case, not being granted full membership in most religions; why should one expect them then to put religion before their felt needs and desires? (in Menon \& Bhasin, 1998). Ironically, it is in probing the lives of women who survived abduction and sometimes rape, and possibly dismemberment, to live through the messy gendered realities of everyday life, that we find the gray areas, the possibilities of threshold existences that defy easy demarcations and watertight constructs of purity. But these gray areas become perceptible through indirect forms such as the testimonies of social workers who were responsible to rehabilitate the women, and particularly in the fictional accounts taken up in the next section.

Coming back to my mother's stories, then, it becomes possible to understand a bit better why my mother stops at an abstract notion of honor rather than probing the concrete experience of abduction and life afterward. Veena Das (1997) describes a "zone of silence" in the stories of women who were abducted and/or raped, a silence she says "was achieved either by the use of language that was general and metaphoric and that evaded specific description ... or by describing the surrounding events but leaving the actual experience of abduction and rape unstated" (p. 84). In my mother's case, I think the silence has another important layer to it, a layer of protection afforded by class position. My father, who was then engaged to my mother, was able to charter an airplane to take her and his own family across the newly created border to safety. My mother therefore never had to face the actual experience of violation either directly or through close family and friends. In having been afforded a safe crossing in actual terms, she did not have to experience the metaphorical crossing to the other side of honor, toward the threshold of social death. Unlike the women who told Das that they had imbibed the secret knowledge of rape deep within themselves as a poison, or felt like discarded exercise books, my mother's brush with the possibility of violence was through the vials of cyanide and the cries of the women in the neighborhood. Even she had to do the work of assimilating the disorder of the partition, but not quite in the same way as the abducted women. My mother transformed passivity into agency by dwelling on the domestic aspects of the upheaval. She tells the story of her mother making pinnis (sweet balls made of flour and sugar) for their passage across the border so that they would have some source of nourishment in a very uncertain situation; these very same pinnis were offered to the pilot of the chartered plane as further assurance of safe passage. She also dwells repeatedly on the suddenness of the departure, and the fact that the women wore several layers of clothing so they would have something to wear in the coming days. These were ways in which the women transformed disorder into a modicum of comfort and familiarity. Within my mother's class position and her particular experience, a kind of domestication works to normalize the cataclysmic event. While my mother and the women in Das' account who experienced rape each in their own way assimilate a disorderly experience into everyday life by making parallels with every day domestic reality (some of the women 
tell Das that as they are consumed every day in any case, what honor is there to uphold in a woman's body, in other words, what is the difference?), my mother does not have to create metaphors or to create a protective zone of silence because she does not have to live with the experience or the knowledge of the experience in her body.

Juxtaposing my mother's stories with the oral histories makes visible the particularity of each experience, especially in terms of class. Expanding out from my mother's stories to the complexity of women's experiences of pain during the Partition brings to light the need to create a home for this pain, and to broaden the possibilities in terms of the responses women can make in conditions when the nation is written on their bodies, rescuing whatever agency is possible when multiple patriarchies would make pawns of them. In the section that follows, I examine how fictional accounts create such a home.

\section{Gender-sensitive fictional representations of the partition}

As demonstrated by Bhaskar Sarkar's (2009) analysis of Partition films and by Kavita Daiya in her analysis of fictional reworkings of Partition in film and literature, the shell of fiction affords the opportunity, in the hands of progressive artists, to open out to new understandings and imaginative possibilities, including understandings of the gendered aspects of the Partition. ${ }^{3}$ New positions of enunciation are created for women, for example, going beyond what can be rescued from oral histories and stories told in the household. Building again from my mother's nugget of a story on the vials of cyanide, what can fictional accounts help us to imagine in terms of possible contestations of hegemonic versions of religious purity and community honor as signified by the safeguarding of women's sexuality, in terms of different subject positions and positions of enunciation women might take in relation to the dominant logics that would use them as pawns in the creation of borders? As Veena Das (1997) has observed in her incisive and oft-cited essay,

Family narratives abound on men who were compelled to kill their women to save their honor. Such family deaths are beatified in family narratives, while women who were recovered from their abductors and returned to their families or who converted to the other religion or made new lives in the homes of their abductors hardly ever find a place in these narratives, although they occur frequently in the literary representations. (p. 84)

Although oral histories and family stories do reveal undercurrents pointing to contradictions between nationalistic ideologies and women's daily lived experience, it is in the space of the imaginary that the experience of suffering, including women's concrete experience of suffering, can find some kind of register, and where other tonalities of women's experience and agency can be broached. While Das aptly reminds us that the task of unearthing hidden aspects or trying to break the silence in the form of historiography is a complicated one, and can indeed be used as a weapon (Das, 1997) in the domain of fiction, it might be possible to probe the liminal spaces 
and existences, such as what Das astutely terms the instable location of abducted women as between social and physical death, as inhabiting a space of living death. As one potent example, both Das (1997) and Daiya (2008) refer to the space-clearing capacity of Saadat Hassan Manto's Urdu short stories, written in the 1940s and 1950s, particularly "The Return.” As Sirajjudin, a Muslim refugee, is fleeing from Amritsar to Lahore (from the Indian side to the Pakistani side) on a train, his wife is killed and he is separated from his 17-year-old daughter, Sakina. When he happens upon a group of Muslim men who represent themselves as rescuers of Muslim women left behind in Amritsar, he beseeches them to find his daughter. They do eventually find her, and after first offering her protection, proceed to rape her repeatedly, unbeknownst to Sirajjudin. Toward the end of the story, Sirajjudin, who has been going from one refugee camp to another trying to locate Sakina, spots her on a stretcher as she is being taken to a hospital. At the hospital, the doctor checks Sakina's pulse. Then, pointing to the window, he asks Sirajjudin to "open it." Even though she is unconscious, the words evoke an automatic response in Sakina. She reaches for the cord of her salwar (loose trousers), and barely being able to move, pulls the salwar down and opens her thighs. Seeing a stirring of his daughter's body, Sirajjudin shouts with joy, "She is alive. My daughter is alive!" The doctor breaks into a cold sweat. Das (1977, p. 77) surmises that "One can read in Manto a transaction between death and life, body and speech, in the figures of the daughter and the father." She says further that the joyful exclamation by the father is significant in that it provides "a home for her mutilated self." In an ideological environment when the dominant mode of masculinity tended toward the sacrificing of one's actual flesh-and-blood daughters in the name of abstractions, the father's gesture is an important reversal. Just as the father's words provide space to express the inexpressible, to create a possibility beyond living death, so too does Manto's story. The ironic juxtaposition of the words "Open it" (khol do) and Sakina's ironic misrecognition is precisely what probes the threshold of silence and language, the threshold upon which unspeakable suffering enters into the stream of ongoing life. The story also opens up space to critique the equation between religious difference and women's abduction and rape. Sakina is raped by men of her own religious affiliation who had promised to protect her, and this points to another aspect of the Partition that is relatively hidden, the sexual exploitation of women by men of their own religion, and not only for reasons of saving the women's reputation or the community's purity. ${ }^{4}$

In the fictional domain, finer shades of gray are also probed surrounding the killing of women for the sake of honor. In What the Body Remembers, for example, Shauna Singh Baldwin (1999) probes the silences surrounding the taking of women's life to save their “izzat.” The main character's (Roop's) father describes to her how he had to behead his daughter-in-law (Roop's sister-in-law) as a mob of Muslim men could be heard in the vicinity making threats.

But Kusum, she was my responsibility ... I cannot endure even the possibility that some Muslim might put his hands upon her. Every day I had been hearing 
that the seeds of that foreign religion were being planted in Sikh women's wombs. No, I said: I must do my duty. (p. 455)

He goes on to describe how Kusum did not flinch, how she turned around so he would not see her face, how she bared her neck to make it easier for him to wield his sword (kirpan). At this point, Roop makes a note to herself that this is the telling she will have to repeat for her brother's sons one day, to tell them of their mother's martyrdom. But the shades of gray open up through the pain Roop feels, and through her gnawing sense that no one can ever know Kusum's pain, her full story. The narrator says, "What is not even in Bachan Singh's [Roop's father's] silence, that Roop must fathom, to know this story?" (p. 457). Here, the narrator is by extension asking the survivors, including possibly the next generations, what is not even in the silences that still pervade Partition stories, that we must fathom, to understand the many layers of the experience, particularly for women, to begin to grasp the pain.

The demarcation of boundaries through the rape of women is also broached in Bapsi Sidhwa's Cracking India (1991). Sangeeta Ray (2000) has noted that "the novel emphasizes the particular plight of women as they become the increasing focus of a definitive ethnicity" (p. 133). Kavita Daiya (2008) hones in on the openings created by the literary treatment of one of the central characters, Ayah (literally "nanny"), who is eventually betrayed by one of her closest friends. Ayah (who is Hindu) is the nanny for Lenny, the 8-year-old Parsi girl from whose point of view the novel is written. ${ }^{5}$ As the novel progresses, Ayah's multiethnic community of friends begins to fracture, echoing the fracturing of communal harmony in the larger context of the Partition. Two critical events create the impetus for her eventual rape. One of her closest friends, Ice-Candy-Man, who is Muslim and who desires her, suffers unbearable pain when his sisters are slaughtered by Hindus on a train. A little later in the story, and partly as a result of Ice-Candy-Man's dehumanization, Ayah chooses another Muslim man, also in her group of close friends, Masseur, as her lover. This combination of affronts, combined with the rising crescendo of hatred and mistrust, leads to Ice-Candy-Man going with a mob to Lenny's house and asking for Ayah to be presented. When other household members pretend that Ayah is no longer present, Ice-Candy-Man tricks Lenny into betraying her whereabouts. The mob then searches the house, forcibly carries her out, and proceeds to rape her in front of the Parsi family and other members of the household. Daiya observes that Sidhwa depicts the rape as a spectacle, from Lenny's perspective, and that these "'telling details' about her lips, throat, mouth, bare feet, torn sleeve, the stitching of the blouse seams, her eyes and hair signify the material, bodily rupture of her everyday in postcolonial Pakistan" (p. 73). As also noted by Daiya, Sidhwa does not attempt to convey Ayah's feelings, her pain, perhaps in a recognition of the inscrutability of that region. However, in translating the violation as visual spectacle, Sidhwa still touches an area left untouched by oral narratives, by nonfictional accounts. It is in fiction that we can begin to imagine the concrete meaning of writing the border on women's bodies. But Daiya also notes that it is Ayah's actions after the rape that open 
up the possibility of a different subject position for women. Ice-Candy-Man lives with Ayah after the rape, persisting in his desire for her. When the two newly created governments begin their project of repatriating women, Ice-Candy-Man marries her. Ayah, on her part, asks Lenny's mother to have her safely escorted to her family across the border in India. In doing so, she asserts agency and rejects abstractions of nationalism and patriarchal community, and rejects the option of suicide. She insists on living, and asserts her own terms. The novel leaves open the question of her reception across the border by her relatives, but in giving Ayah the last word in the novel a significant gesture is made. ${ }^{6}$

I now move to a cinematic representation opening up a different subject position for the abducted woman, that of refusing to be repatriated. This echoes the testimonies of social workers collected by Menon and others, giving examples of women who resisted repatriation because they had accommodated to their new situation, feared rejection by their families, and other reasons (Menon \& Bhasin, 1998). In Pinjar ("Skeleton") created in 2003, and based on Amrita Pritam's novel of that name written in 1950, this terrain is explored further. The story revolves around Puro, who is the daughter of a wealthy Punjabi family in Amritsar and is engaged to Ramchand. She is abducted by a Muslim farmer, Rashid, who subsequently falls in love with her. She escapes from him but her family refuses to accept her back. She tries to commit suicide, but Rashid saves her and gets married to her. Not reconciled to the situation, she refuses to eat and becomes skeleton-like. When the Partition begins, she ends up meeting Ramchand, who tells her that his sister is now married to Puro's brother, pregnant, and has been abducted. Rashid helps Puro locate and rescue Ramchand's sister. In a crucial scene at the end of the film, as Ramchand's sister is being reunited with her husband (who is also Puro's brother), Puro's brother asks her to go across the border with them as well, adding that Ramchand is willing to accept her. Puro refuses to join them, affirming the domestic intimacy she has established with Rashid, affirming the possibility of life after abduction and rape, thereby opening up space for the agency of the abducted and raped woman. As Daiya (2008, pp. 177-178) says, "Thus, Puro, as an agentive subject, makes the nonnormative choice to refuse the offer of inclusion and interpellation into family, community, and nation that was once denied to her. Refusing the nation-both Indian and Pakistani-Pinjar's once Hindu, feminist protagonist embodies and asserts her choice of the abductor/Muslim man as life partner."'

\section{Bringing the stories together}

Apart from opening up another possible subject position for the abducted woman, the culminating scene in Pinjar points to another strong undercurrent running through my mother's stories, the oral histories, and being developed further in the fictional domain, the possibility of deep attachment and sense of belonging regardless of national borders and religious boundaries, the other side of which is the unshakeable and lasting sense of loss of this deep sense of human connection. Starting again with 
my mother's stories, her account of the vials of cyanide sits side by side with another one that was often repeated. She says that as the violence intensified leading up to August 1947 and her brother was trying to decide whether to stay or leave, their kind Muslim neighbor said, "Your sisters are my sisters. If the mobs attack your house, your sisters can simply jump the wall into our house. I give my word that they will be protected." The persistence of this fragment in my mother's memory speaks to a sense of loss, and its obverse, yearning. In the oral histories of the Partition from a gendered perspective, it becomes possible to unearth this other aspect of nation-making interred by the nationalistic dominant paradigm: the humanity and fellow feeling that survives in the throes of large-scale communal violence, as well as the ties of love and friendship that defy notions of honor, religion, and nation. Social worker Manikuntala Sen (2004), in the oral histories collected by Menon, recounts the "indomitable courage, strength of mind, and humanitarianism" (p. 59) of a Muslim couple who sheltered Hindu Communist party workers for 3 days, fending off suspicious neighbors and thereby saving the lives of the workers. She also tells of a number of Muslim and Hindu families in Calcutta setting up a network to transport members of the other community to safe neighborhoods. Ismat Chughtai writes of the unbearable emotional loss entailed by Partition, but a loss that has within it the seeds of a burning desire for reconciliation. She says, "Those whose bodies were whole had hearts that were splintered. Families were torn apart. One brother was allotted to Hindustan, the other to Pakistan; the mother was in Hindustan, her offspring were in Pakistan. The bonds of human relationships were in tatters, and in the end many souls remained in Hindustan while their bodies started off for Pakistan" (Chughtai, 2004, p. 40). The loss continues to have powerful effects, and continues to sow the seeds of desire. Menon points to how starkly the arbitrariness of borders and cost to humanity is felt in the actual, physical borderlands. One such war-torn borderland is Kashmir, the still contested, still unresolved legacy of Partition, still taking its toll in blood and heartbreak. In the border town of Uri, there are many examples of families torn apart by the Partition. Haji Assadullah, 77, has been separated from his three brothers and three sisters since November 1947. In Asida village, "every resident has a family member living on the other side." (Menon, 2004a, p. 6). Bibi Jaan, 72, has not seen her two brothers and their families for 50 years. They live $2 \mathrm{~km}$ away, but she has to travel hundreds of miles to cross the closest official border, which she cannot afford. She could not see her parents before they died. "She says the time has come to demolish this 'line of hatred' and pass on a legacy of love to the next generation" (Menon, 2004a, p. 6).

This yearning is further probed in the fictional domain. Sarkar (2009) takes up the interesting case of Apna Desh, made in the late 1940s by the well-known filmmaker V. Shantaram. The film's Hindu woman protagonist, Mohini, is raped in Pakistan, and arrives in India as a refugee. She is shunned by her relatives. She becomes alienated by her surroundings, and finds purpose and solace in the close connections she retains with people in Pakistan, sending arms and clothes across the border. Her divided loyalties created a strong backlash among Hindus in India, to the extent of 
demanding a ban on the film. Sarkar points out that the National Film Archives in Pune hold most of Shantaram's films, but Apna Desh cannot be found anywhere. Sarkar sees the disappearance of the film as an index of the threat it presented to the dominant ideology that equated women's honor with religious purity and nation formation. This equation was a necessary ideological support in the process of nation formation, and it did not allow for alternatives to the victimized or martyred woman subsumed to the nation. In this scheme, a sullied woman who asserted not only her existence after rape, but her affinity with people across the border, was very likely a considerable threat.

Decades later, the yearning continues as a thread in fiction, a yearning that takes on particular poignancy with the recognition of the possible failure of the secularist project within India, evidenced by repeated riots between Hindus and Muslims, and Hindu riots against Sikhs in 1984. Sarkar (2009) says the killing in 1984 of more than 2,000 Sikhs by Hindus provided an impetus for the creation of the miniseries Tamas in an attempt to rewrite national history in a way that acknowledges continuities with the past in terms of sectarian strife. Tamas itself aired in 1988, and was only the second televised series to directly address the Partition. Although the yearning for communal harmony manifests itself within a nationalist mold, it is very much present in Tamas. Sarkar says:

the miniseries dramatizes instances of valiance, when people risk their own lives to defend their neighbors belonging to another sect. These are the most powerful and moving images that linger in spectators' minds long after the episodes are over: a Hindu woman defends her neighbor, a Muslim teacher she calls her brother, sword in hand; a Muslim woman provides shelter to Harnam and Banto [the Sikh elderly couple] against her family's wishes; Muslim Shahnawaz Khan escorts the Hindu merchant Lalaji and his family to a safe, Hindu-majority neighborhood, without concern for his own safety. (p. 240)

Although these aspects echo nationalist historiography, in the esthetic rendering, conveying the texture of relationships with emotional force, the yearning for reconciliation is nevertheless conveyed, and mapped onto a current yearning for communal harmony within the Indian context (Mankekar, 1999, p. 304-306). ${ }^{8}$

\section{Discussion}

What are we able to learn, then, from the juxtaposition of narratives? Let me start again with my mother's stories. The story about the vials of cyanide speaks to her personal relief that she did not become one of the abducted and raped women, thus remaining within the fabric of family and community. This is accentuated by her ritualistic reference to the fact that had she neared the possibility of rape, her brother would have shielded her with cyanide, that she would not under any circumstances have undergone a social death. In her repetition of the cyanide story she stays within the imperative of the bounds of ideal Hindu femininity, accepting of the 
victimization and martyrdom of the woman but not of her self-determination after rape. Only her nightmares betray an empathic connection with others who did cross over to the other side, who did experience abduction and very possibly rape. Yet even the nightmares stop at the point of the victimization of "other" nameless, faceless women. They remain disembodied as screams. These are never concretized, and the afterlife of the abducted woman is not broached in any way, not even as ruminations of what might have happened to the women. The story of the kind Muslim neighbor speaks to the rupture in everyday life and harmonious everyday relations created by the Partition. Even as the general tendency in the stories is one of growing mistrust of Muslims and fear of potential victimization by the Muslim men, the figure of the Muslim neighbor offering protection remains a constant thread. As against the possibility of attack by Muslims as an amorphous mob stands the concreteness of the kindness of a Muslim neighbor. Trying to tie the fragments together, then, an undercurrent of yearning and empathy is perceptible in her accounts, and also an undercurrent of domesticity seeking from the sudden rupture of attachments some semblance of normalcy, but the main contours remain within the mold of the national imaginary of the need to maintain the purity of the religion through the protection of women. Martyrdom is ultimately the only really valorized position for women in my mother's stories, as even the victimization of women remains abstract. This accords with the general disposition of the families of victimized women. While there was a stance of collective mourning and outrage on the part of families and communities with regard to the brutality of the violence against women, the actual victimized women were not readily admitted back into the community and even into the narratives. As my mother's stories and the oral histories both suggest, a zone of silence surrounds the actual experience of women's violation and their life after rape and/or abduction, even though the exact characteristics of, and the motivating factors behind, the silence appear to be conditioned by class and caste position. Notions of women's honor are accentuated in my mother's stories, echoing the dominant ideologies particularly among upper-caste, upper-middle-class Hindu communities, these in turn echoing a particular bourgeois suturing of the identity of the modern Indian woman as adopting the accoutrements of Western enlightenment on the surface while retaining the spiritual purity of a Vedic past (Chatterjee, 1989; Jayawardena, 1986).

The oral histories and autobiographical narratives gathered by Menon and Bhasin and Bhutalia make it possible to put particular stories such as my mother's into larger perspective. The multiplicity of experiences also allows for a glimpse into other possibilities in terms of women's agency and affiliation across borders. Although the oral histories also privilege stories of women's martyrdom on the one hand and victimization at the hands of men of the "other" community on the other, just as my mother's stories do, in acknowledging the experience of abducted women who made a new life, sometimes created new homes across religious lines, and sometimes resisted repatriation, it becomes at least possible to speak of subject positions for women other than victim or martyr, opening up the possibility of resistance to the workings 
of patriarchy at both the community and national level. It also becomes possible to at least begin to speak of affiliations across lines of religion and community even as borders are being violently drawn, affiliations that defy easy encapsulation in the dominant constructions of nation and religious affiliation. These countercurrents, although more accessible in the oral histories than in my mother's stories, still have to be teased out from the contradictions in the social workers' testimonies, and from the occasional and reluctant fragment in the oral histories of the "ordinary" women who witnessed violence against other women closely related to them.

In contradistinction, it is in the domain of fiction that the imagination can open out to other discrete possibilities, and these possibilities can be inhabited more fully, even if still tentatively so. As pointed out by Das (1997), it is in the domain of fiction that women's pain is given a home, where it begins to be given a certain level of concreteness, where it begins to be embodied. Through the painstaking details of Ayah's rape in Cracking India, through the abjectness of Sakina's condition in The Return as she opens her thighs in response to the doctor's request to open the windows, through the detailed description of the beheading of Kusum in What the Body Remembers, the pain that women experienced begins to be embodied, to be given concrete form and shape, to be acknowledged. It is also through fiction that we begin to glimpse women's agency in a way different from that available through my mother's stories, and only available as we read against the grain of ordinary women's and social workers' accounts in the oral histories gathered by Menon and Bhasin (1998) and Butalia (1998). Through Mohini in Apna Desh, who sends arms and clothes to Pakistan, or through Puro in Pinjar, who refuses to return to India, or through Ayah in Cracking India, who insists on returning to India and refuses the love of Ice-Candy Man after rape, it is through them that we can imagine other, more liberating options for women as they are caught between competing imperatives of nation, community, and gender. By offering possible responses and options to women rarely available in other domains, the fictional explorations expand the space for the elaboration of Indian women's subjectivity.

In some measure, even with the contradictions and limitations that inhere in each of the kinds of narratives explored here, together they provide a counterpoint to the official narratives. The inclusion of women's personal narratives, in combination with gender-sensitive fictional representations, contributes to a theory of history which is more accurate and inclusive because it begins with the lived experience of those neglected by official accounts. This counterpoint is essential both for the expansion of the imaginative possibilities for Indian women's subjectivity, and also for contesting the dominant accounts of nation formation and all that it entailed. The narratives, even as they are shaped by dominant ideologies, still carry within them potent traces of other experiences, other voices that are essential to recuperate. While this is more explicitly so in the fictional explorations, each of the narratives provides an important counterpoint to the others, and taken together they allow us to write a history from below, a history that more fully contends with women's pain and women's agency as they negotiated the violence wrought upon them in the name of nation and community. 


\section{Acknowledgment}

I dedicate this article to my late father's memory, in gratitude for always being inspired by his great mind and even greater heart.

\section{Notes}

1 Although I have selected here aspects of my mother's stories that speak to the themes central to this article, I should add that another frequent strain in her stories is the suddenness of the departure and the need to leave all belongings behind, including her brother's entire dispensary (small-scale pharmacy for a single practitioner).

2 As Veena Das (1997) points out, the frequency of such rejections may have been amplified in oral accounts, but their existence as a repeated motif does convey the power of the myth that families would rather sacrifice their daughter than sully the purity of the family, community, and religion.

3 I make no pretense here of being exhaustive in my treatment of fictional narratives. There are many other films, short stories, and novels that could have been included. In my selection I was guided by the criterion that the works should make a significant intervention into the way we understand and imagine the position and responses of ordinary women upon whom violence was inflicted during the Partition.

4 Manto is singled out by both Das (1997) and Daiya (2008) for the liberatory potential his stories hold. His feminist sensibilities come through clearly. In including him here, I join others in refusing to conflate the gender of the author with the gendered content of the narrative.

5 The Parsi community in India was considered neutral, not belonging to the Hindu, Muslim, or Sikh communities involved in the bloodshed during the Partition. Sidhwa has purposely written Cracking India from the vantage point of a Parsi girl to expose the duplicities of the communities involved.

6 Deepa Mehta uses Cracking India as the basis of her cinematic depiction of the Partition in the film Earth, part of her globally distributed trilogy. Both Daiya (2008) and Sarkar (2009) offer an incisive critique of Mehta's film, generally coming to the conclusion that she does not exploit the liberatory possibilities of the novel but forecloses these possibilities. As one example, Earth ends with Ayah's rape, rather than with her relocation to India at her own insistence as in the novel.

7 I have admittedly had to be very selective in my discussion of cinematic representations of the Partition, focusing mainly on what I considered to have an explicitly gendered aspect and that went beyond dominant nationalistic understandings. Even then, I have left out important creative projects such as visual artist Nalini Malani's video installation Mother India: Transactions in the Construction of Pain (2005) discussed by Marino (2010). Interestingly, Malani jumps off of Veena Das' (1997) essay, referenced here earlier, to show through a collage of narratives how the nation is written on women's bodies. It is the refusal to sew things up, to form a whole from the disparate fragments that gives Malani's piece its power. While I did not feel I had enough access and insight into Malani's work to be able to include it at this point, it obviously is an important creative foray in terms of a gendered counterhistory of the Partition and should be studied further. 
8 Both Mankekar (1999) and Sarkar (2009) discuss episode 5 of the miniseries Tamas, ending with Sikh women embracing death by collectively jumping into a well to avoid capture at the hands of Muslim men. Both reach the conclusion that in general the scene fails to interrogate the suturing between community, gender, and honor that created such terrible consequences for women. Rather, it repeats the equation between women's purity and the community's honor.

\section{References}

Anthias, F., \& Yuval-Davis, N. (1992). Racialized boundaries: Race, nation, gender colour and class and the anti-racist struggle. London, England: Routledge.

Baldwin, S. S. (1999). What the body remembers. New York, NY: Anchor Books.

Bhattacharyya, G. (2008). Dangerous brown men: Exploiting sex, violence and feminism in the war on terror. New York, NY: Zed Books.

Butalia, U. (1998). The other side of silence: Voices from the partition of India. New Delhi, India: Viking.

Chang, H. (2008). Autoethnography as method. Walnut Creek, CA: Left Coast Press.

Chakravarti, U. (1989). Whatever happened to the Vedic Dasi? Orientalism, nationalism and a script for the past. In K. Sangari, \& S. Vaid (Eds.), Recasting women: Essays in Indian colonial history (pp. 233-253). New Delhi, India: Kali for Women.

Chatterjee, P. (1989). The nationalist resolution of the women's question. In K. Sangari, \& S. Vaid (Eds.), Recasting women: Essays in Indian colonial history (pp. 233-253). New Delhi, India: Kali for Women.

Chugtai, I. (2004). Communal violence and literature. In R. Menon (Ed.), No woman's land: Women from Pakistan, India and Bangladesh write on the partition of India (pp. 40-54). New Delhi: Women Unlimited.

Daiya, K. (2008). Violent belongings: Partition, gender, and national culture in postcolonial India. Philadelphia, PA: Temple University Press.

Das, V. (1997). Language and body: Transactions in the construction of pain. In A. Kleinman, V. Das, \& M. Lock (Eds.), Social suffering (pp. 67-118). Berkeley, CA: University of California Press.

Jayawardena, K. (1986). Feminism and nationalism in the third world in the 19th and early 20th centuries. London, England: Zed Books.

Jiwani, Y. (2006). Discourses of denial: Mediations of race, gender and violence. Vancouver, Canada: UBC Press.

Lowe, L. (1991). Critical terrains: French and British Orientalisms. Ithaca, NY: Cornell University Press.

Mani, L. (1989). Contentious traditions: The debate on sati in colonial India. In K. Sangari, \& S. Vaid (Eds.), Recasting women: Essays in Indian colonial history (pp. 88-126). New Delhi, India: Kali for Women.

Mankekar, P. (1999). Screening culture, viewing politics: An ethnography of television, womanhood, and nation in postcolonial India. Durham, NC: Duke University Press.

Marino, A. (2010). Dismembering and re-membering Mother India: Women's trauma, partition, and the Indian nation. Feminist Media Studies, 10(2), 241-243. 
Menon, R. (2004a). No woman's land. In R. Menon (Ed.), No woman's land: Women from Pakistan, India and Bangladesh write on the partition of India (pp. 1-11). New Delhi: Women Unlimited.

Menon, R. (2004b). Border crossings: Travelling without a destination. In R. Menon (Ed.), No woman's land: Women from Pakistan, India and Bangladesh write on the partition of India (pp. 121-134). New Delhi: Women Unlimited.

Menon, R., \& Bhasin, K. (1998). Borders and boundaries: Women in India's partition. New Delhi, India: Kali for Women.

Rajan, R. S. (1993). Real and imagined women: Gender, culture and postcolonialism. London, England: Routledge.

Ray, S. (2000). En-gendering India: Woman and nation in colonial and postcolonial narratives. Durham, NC: Duke University Press.

Sangari, K., \& Vaid, S. (1989). Recasting women: An introduction. In K. Sangari, \& S. Vaid (Eds.), Recasting women: Essays in Indian colonial history (pp. 88-126). New Delhi, India: Kali for Women.

Sarkar, B. (2009). Mourning the nation: Indian cinema in the wake of Partition. Durham, NC: Duke University Press.

Sen, M. (2004). Riots, partition and independence. In R. Menon (Ed.), No woman's land: Women from Pakistan, India and Bangladesh write on the partition of India (pp. 55-68). New Delhi: Women Unlimited.

Sinha, M. (1995). Colonial masculinity: The "Manly Englishman" and the "Effeminate Bengali" in the late nineteenth century. Manchester, England: Manchester University Press.

Spivak, G. (1987). In other worlds: Essays in cultural politics. New York, NY: Methuen. 